\title{
Effect of Cold Exposure on Insulin Responsiveness to Glucose and Tissue Responsiveness to Insulin in Sheep Given Ad Libitum Access to Roughage
}

\author{
Hiroaki Sano ${ }^{*}$, Kaoru Ōrshi and Yoshiaki Terashima \\ Faculty of Animal Science, Kitasato University, \\ Towada-shi 034
}

(Received April 1, 1993)

\begin{abstract}
Hyperglycemic clamp and hyperinsulinemic euglycemic clamp techniques were applied to investigate the effect of cold exposure on insulin responsiveness to glucose and tissue responsiveness to insulin in sheep given ad libitum access to roughage. Daily dry matter intake was not influenced by cold exposure. In the hyperglycemic clamp experiment, the ratio of plasma insulin increment to glucose infusion rate (insulin responsiveness to glucose) was reduced by cold exposure $(P<0.05)$. In the hyperinsulinemic euglycemic clamp experiment, the glucose infusion rate (tissue responsiveness to insulin) was higher $(P<0.01)$ during cold exposure than in the thermoneutral environment. These results suggest that ad libitum access to roughage does not influence reduced insulin responsiveness to glucose and enhanced tissue responsiveness to insulin during cold exposure in sheep whose voluntary intakes did not increase.

Anim. Sci. Technol. (Jpn.) 64 (10): 971-977, 1993
\end{abstract}

Key words: glucose clamp technique, insulin, sheep, ad libitum feeding, cold exposure

Insulin is one of the most important hormones to control nutrient metabolism in both ruminant and nonruminant animals. It has been reported in sheep under some feeding regimens that insulin responsiveness to glucose (glucose-induced insulin secretory response) was reduced and tissue responsiveness to insulin (insulin action to tissue) was enhanced during cold exposure using the glucose clamp technique ${ }^{3,11}$. They were also influenced by feeding levels ${ }^{87}$ and type of $\operatorname{diet}^{3)}$. Moreover, ad libitum roughage inlake increases heat production $^{10)}$, and enhanced heat production may relieve the effect of cold stress. Therefore, we postulated that ad libitum roughage intake might affect insulin responsiveness to glucose and tissue responsiveness to insulin differently from those obtained in cold-exposed sheep fed a diet at maintenance level ${ }^{11)}$ or a mixed diet of concentrate and roughage ${ }^{3)}$. However, no information has been available about insulin responsiveness to glucose and tissue responsiveness to insulin using the glucose clamp technique during cold exposure in sheep given ad libitum access to roughage.

The objective of this experiment was to investigate the effect of cold exposure on insulin responsiveness to glucose and tissue responsiveness to insulin using the hyperglycemic clamp and hyperinsulinemic euglycemic

\footnotetext{
* Present address : Faculty of Agriculture, Iwate University, Morioka-shi 020
}

Anim. Sci. Technol. (Jpn.) 64 (10) : 971-977 971 
clamp techniques in sheep given ad libitum access to roughage.

\section{Materials and Methods}

Animals and Diets: Nine Suffolk shorn rams aged 2 to 3 years and weighing about 50 $\mathrm{kg}$ were used. They were surgically prepared with a skin loop enclosing the left carotid artery. Animals were initially kept in metabolism cages in an environment controlled chamber at $20 \pm 1^{\circ} \mathrm{C}$ for more than a month. After the end of the experiment in the thermoneutral environment, the animals were exposed to $0^{\circ} \mathrm{C}$. The experimental diet was chopped orchardgrass hay (moisture 12.2\%, crude protein $14.1 \%$, ether extract $3.8 \%$, crude fiber $24.4 \%$, crude ash $8.4 \%$ and nitrogen free extract $37.1 \%$ ), and was given ad libitum access to feed. The diet and water were given at $16: 00 \mathrm{~h}$. Catheters for infusions and blood sampling were inserted into a jugular vein at least 2 days and into the skin loop enclosing at least 2 hours before the experiment, respectively.

Glucose Clamp: The hyperglycemic clamp experiment was carried out to determine insulin responsiveness to glucose (glucose-induced insulin secretory response) on day 11 of the thermoneutral and cold exposure. The preinfusion blood glucose concentrations were determined three times by a glucose analyzer immediately before the glucose infusion. At 13: $00 \mathrm{~h}$ glucose solution $(20 \%(\mathrm{~W} / \mathrm{V}))$ was infused by a multichannel peristaltic pump (Model AC-2120, Atto Co. Ltd., Tokyo) through the jugular catheter for 2 hours, and blood glucose concentrations were designed to achieve $50 \mathrm{mg} / \mathrm{d} l$ above preinfusion levels (mean of three determinations) during the glucose infusion period. Blood samples $(1 \mathrm{ml})$ were taken from the arterial catheter every $5 \mathrm{~min}$ and blood glucose concentrations were determined by the glucose analyzer within $1 \mathrm{~min}$ after taking each blood sample. Then, the glucose infusion rate was adjusted to main- tain the desired blood glucose concentrations. Blood samples $(3 \mathrm{ml})$ taken at $10-\mathrm{min}$ intervals were stored in ice-water until centrifugation. The glucose infusion rate of 10 -min intervals was recorded throughout the glucose infusion period.

The hyperinsulinemic euglycemic clamp experiment was carried out to determine tissue responsiveness to insulin (insulin action to tissue) on day 14 of both environments. Immediately after the determination of the preinfusion blood glucose concentrations, insulin (400 U/l ; Actrapid monocomponent porcine insulin, Novo Industry, Denmark) dissolved in $0.9 \%$ sodium chloride and $2.5 \%$ potassium chloride was infused continuously by the peristaltic pump at the rate of $6.0 \mathrm{mU} / \mathrm{kg} / \mathrm{min}$ for 2 hours starting at $13: 00 \mathrm{~h}$. Blood glucose concentrations were determined every $5 \mathrm{~min}$, and glucose solution (20\%) was infused by other peristaltic pump to maintain the preinfusion blood glucose concentrations. Glucose infused was recorded every $10 \mathrm{~min}$ as described in the hyperglycemic clamp experiment.

Analyses: Blood glucose concentrations were determined by the glucose analyzer (Model GLU-1, Erma Optical Works Ltd., Tokyo). In the hyperglycemic clamp experiment residual blood samples were centrifuged at $10,000 \times \mathrm{g}$ for $10 \mathrm{~min}$ at $4^{\circ} \mathrm{C}$, and stored at $-20^{\circ} \mathrm{C}$ until assayed for insulin. Plasma insulin was assayed by radioimmunoassay as described previously" ${ }^{4}$.

Calculations: The glucose infusion rate and the increase in plasma insulin concentrations over the preinfusion level during the last 40 min of the 2-hour period of the glucose clamp experiment were termed the glucose infusion rate (GIR) and the mean plasma insulin increment (MPII), respectively ${ }^{4}$.

Differences between the preinfusion mean and values obtained during glucose or insulin infusions were evaluated by Student's paired $t$-test. Differences between the thermoneutral and cold exposure on parameters of physiologi- 
cal responses, insulin responsiveness to glucose and tissue responsiveness to insulin were analyzed by analysis of variance using the General Linear Model procedure of the Statistical Analysis System ${ }^{5}$.

\section{Results}

Physiological Responses: Body weight and dry matter (DM) intake of sheep were unchanged during cold exposure (Table 1). Heart rate increased $(P<0.01)$, and respiration rate $(P<0.05)$ and rectal temperature $(P<0.05)$ decreased during cold exposure.

Hyperglycemic Clamp: The preinfusion concentrations of blood glucose and plasma insulin were not different between the thermoneutral and cold exposure (Fig. 1 and Table 2). Blood glucose concentrations increased $(P<0.01)$ accompanied by glucose infusion, and were almost maintained at $50 \mathrm{mg} / \mathrm{d} l$ above the preinfusion levels during the last hour of glucose infusion in both environments. The glucose infusion rates were stable at least for the last $50 \mathrm{~min}$ of glucose infusion in both

Table 1. Effect of cold exposure on body weight, dry matter intake, ME intake, respiration rate, heart rate and rectal temperature in sheep given a roughage diet ad libitum

\begin{tabular}{|c|c|c|c|c|c|}
\hline & \multicolumn{2}{|c|}{ Thermoneutral } & \multicolumn{2}{|c|}{ Cold exposure } & \multirow{2}{*}{ Significance } \\
\hline & Mean & $\mathrm{SE}$ & Mean & $\mathrm{SE}$ & \\
\hline Body weight $(\mathrm{kg})$ & 51.7 & 1. 2 & 52.1 & 1.2 & NS \\
\hline Dry matter intake $(\mathrm{kg} /$ day $)$ & 1.19 & 0.09 & 1. 18 & 0.12 & NS \\
\hline ME intake (Mcal/day) $)^{\mathrm{a}}$ & 2.41 & 0.18 & 2. 39 & 0.24 & NS \\
\hline Respiration rate $\left(\mathrm{min}^{-1}\right)$ & 39 & 6 & 23 & 1 & * \\
\hline Heart rate $\left(\mathrm{min}^{-1}\right)$ & 74 & 4 & 100 & 6 & ** \\
\hline Rectal temperature $\left({ }^{\circ} \mathrm{C}\right)$ & 39.1 & 0.1 & 38.5 & 0.1 & * \\
\hline
\end{tabular}

${ }^{3}$ Calculated

${ }^{*} P<0.05$

${ }^{* *} P<0.01$

$\mathrm{NS}=$ not significant

Table 2. The concentrations of blood glucose and plasma insulin and glucose infusion rate in the hyperglycemic clamp experiment in sheep given a roughage diet ad libitum

\begin{tabular}{|c|c|c|c|c|c|}
\hline & \multicolumn{2}{|c|}{ Thermoneutral } & \multicolumn{2}{|c|}{ Cold exposure } & \multirow{2}{*}{ Significance } \\
\hline & Mean & $\mathrm{SE}$ & Mean & $\mathrm{SE}$ & \\
\hline Basal glucose $(\mathrm{mg} / \mathrm{d} l)$ & 51 & 2 & 53 & 2 & NS \\
\hline Clamped glucose $(\mathrm{mg} / \mathrm{d} l)$ & 103 & 2 & 104 & 1 & NS \\
\hline $\operatorname{GIR}^{a}(\mathrm{mg} / \mathrm{kg} / \mathrm{min})$ & 3. 10 & 0.36 & 4. 08 & 0.44 & $*$ \\
\hline Basal insulin $(\mu \mathrm{U} / \mathrm{m} l)$ & 28 & 2 & 24 & 3 & NS \\
\hline $\mathrm{MPII}^{\mathrm{b}}(\omega \mathrm{U} / \mathrm{m} l)$ & 84 & 13 & 71 & 14 & NS \\
\hline MPII/GIR & 28 & 3 & 17 & 1 & * \\
\hline
\end{tabular}

${ }^{\mathrm{a} G I R}=$ glucose infusion rate during the last $40 \mathrm{~min}$ of glucose infusion period.

$\mathrm{MPII}=$ mean plasma insulin increment during the last $40 \mathrm{~min}$ of glucose infusion period.

${ }^{*} P<0.05$

$\mathrm{NS}=$ not significant 

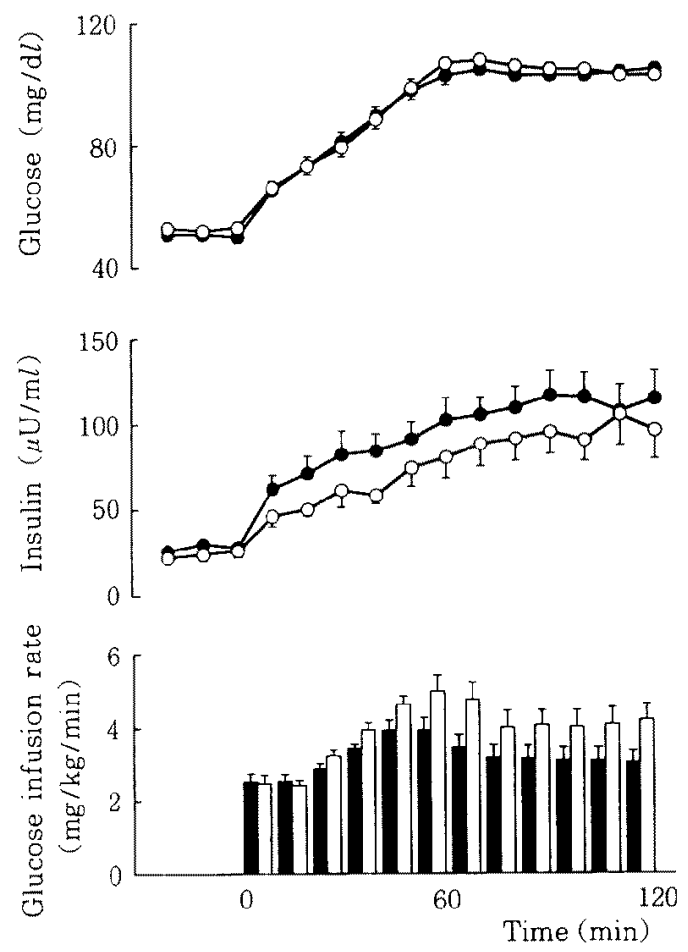

Fig. 1. The concentrations of blood glucose and plasma insulin, and glucose infusion rate before and during the hyperglycemic clamp experiment in sheep exposed to the thermoneutral (solid symbols) and cold (open symbols) environments. Data are expressed as mean \pm $\mathrm{SE}$ of nine sheep.

environments, although they changed during the initial period. The GIR was higher $(P<0.05)$ during cold exposure than in the thermoneutral environment. Plasma insulin concentrations increased $(P<0.01)$ together with increases in blood glucose concentrations, and were stable during the last hour of glucose infusion in both environments. The MPII tended to be lower during cold exposure than in the thermoneutral environment. The ratio of MPIl to GIR was lower $(P<0.05)$ during cold exposure than in the thermoneutral environment.

Hyperinsulinemic Euglycemic Clamp: The preinfusion concentrations of blood glucose were higher $(P<0.05)$ during cold exposure

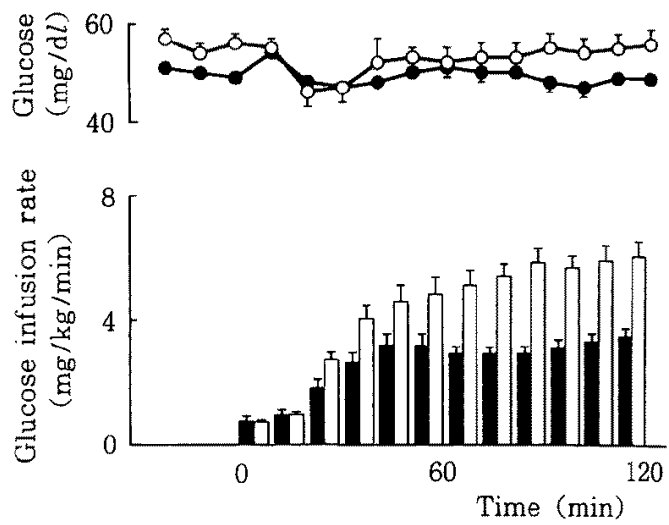

Fig. 2. The concentrations of blood glucose and glucose infusion rate before and during the hyperinsulinemic euglycemic clamp experiment in sheep exposed to the thermoneutral (solid symbols) and cold (open symbols) environments. Data are expressed as mean \pm $\mathrm{SE}$ of nine sheep.

than in the thermoneutral environment (Fig. 2 and Table 3). Blood glucose concentrations changed $(P<0.05)$ initially from the preinfusion values, and were maintained at the preinfusion levels during the latter period of the hyperinsulinemic euglycemic clamp experiment. The glucose infusion rate continued to increase initially, but it was almost stable during the last hour of the 2-hour period in both environments. The GIR was higher $(P<0.01)$ during cold exposure than in the thermoneutral environment.

\section{Discussion}

Environmental temperatures above or below the thermoneutral zone will increase energy needs ${ }^{2}$. KENNEDy and Milligan ${ }^{1)}$ showed that DM intake increased and DM digestibility decreased during cold exposure $\left(2-5^{\circ} \mathrm{C}\right) \mathrm{com}$ pared with a thermoneutral environment (22$25^{\circ} \mathrm{C}$ ) in sheep. However, DM intake of sheep was not influenced by cold exposure $\left(0^{\circ} \mathrm{C}\right)$ in the present experiment. This discrepancy might be involved in species and forms of diets used. Perhaps, the sheep consumed the diet at maximum even in the thermoneutral 
Table 3. The concentrations of blood glucose and glucose infusion rate in the hyperinsulinemic euglycemic clamp experiment in sheep given a roughage diet ad libitum

\begin{tabular}{|c|c|c|c|c|c|}
\hline & \multicolumn{2}{|c|}{ Thermoneutral } & \multicolumn{2}{|c|}{ Cold exposure } & \multirow{2}{*}{ Significance } \\
\hline & Mean & $\mathrm{SE}$ & Mean & SE & \\
\hline Basal glucose $(\mathrm{mg} / \mathrm{d} l)$ & 50 & 1 & 56 & 2 & $*$ \\
\hline Clamped glucose $(\mathrm{mg} / \mathrm{d} l)$ & 49 & 1 & 55 & 3 & NS \\
\hline $\mathrm{GIR}^{\mathrm{a}}(\mathrm{mg} / \mathrm{kg} / \mathrm{min})$ & 3.16 & 0.22 & 5.80 & 0.41 & $* *$ \\
\hline
\end{tabular}

${ }^{a} \mathrm{GIR}=$ glucose infusion rate during the last $40 \mathrm{~min}$ of glucose infusion period.

${ }^{*} P<0.05$

${ }^{* *} P<0.01$

NS $=$ not significant

environment. It has been reported that insulin responsiveness to glucose was decreased and tissue responsiveness to insulin was enhanced during cold exposure $\left(0^{\circ} \mathrm{C}\right)$ in sheep using the glucose clamp technique ${ }^{3,11}$. These experiments were carried out in sheep fed fixed levels of diets. Insulin responsiveness to glucose was enhanced and tissue responsiveness to insulin tended to be enhanced in sheep received a high energy diet ${ }^{8)}$, and heat production in animals consuming fibrous diets was higher ${ }^{10}$. Therefore, it is possible that the responses to cold exposure of insulin responsiveness to glucose and tissue responsiveness to insulin in sheep given ad libitum access to roughage might differ from those obtained in sheep fed fixed levels of diets ${ }^{3,11}$. However, in the present experiment, the effect of cold exposure on insulin responsiveness to glucose and tissue responsiveness to insulin was similar in sheep fed fixed levels of diets ${ }^{3,11}$. A possible reason for this might be unchanged DM and estimated metabolizable energy intakes of sheep during cold exposure.

In the hyperglycemic clamp experiment the GIR was higher $(P<0.05)$ during cold exposure than in the thermoneutral environment. This may be due to the accelerated glucose turnover rate during cold exposure ${ }^{9}$. Although the MPII during glucose infusion was not different, the ratio of MPII to GIR (insulin responsiveness to glucose) was lower $(P<0.05)$ during cold exposure than in the thermoneutral environment. This suggested that insulin responsiveness to glucose was decreased during cold exposure. The reduced insulin responsiveness to glucose during cold exposure might be mediated via activation of adrenergic $\alpha$ receptor of sympathetic nervous system as described by SASAKI and TAKAHASHI ${ }^{6,7)}$. The similar results were obtained in sheep fed a high-concentrate diet, but the ratio was unchanged during cold exposure in sheep fed a high-roughage diet using the hyperglycemic clamp technique ${ }^{3)}$.

Although plasma insulin concentrations were not determined in the hyperinsulinemic euglycemic clamp experiment, plateaus in plasma insulin concentrations were reported in sheep infused at the same rate as the present experiment $(6 \mathrm{mU} / \mathrm{kg} / \mathrm{min} \text { for } 2 \text { hours })^{4)}$. Both blood glucose concentrations and the glucose infusion rate were stable during the last hour of insulin infusion in both environments. Therefore, the GIR (tissue responsiveness to insulin) was comparable, and were higher $(P<0.01)$ during cold exposure than in the thermoneutral environment. Dose-response experiments of hyperinsulinemic euglycemic clamp were not carried out, however, WEEKEs et al. ${ }^{11)}$ suggested that cold exposure might increase the responsiveness of postreceptor events to insulin action without affecting insulin binding to its receptor. Therefore, tissue responsiveness to 


\section{SANO, $\bar{O}_{\text {ISHI }}$ and TERASHIMA}

insulin during cold exposure was enhanced due to increases in intracellular disposal of glucose accompanied by depletion of glycogen in the insulin-sensitive tissues such as the portal drained viscera and skeletal muscle. In conclusion, insulin responsiveness to glucose was reduced and tissue responsiveness to insulin was enhanced during cold exposure in sheep given a roughage diet ad libitum without changing in voluntary intakes.

\section{References}

1) Kennedy, P.M. and L.P. Milligan. Effects of cold exposure on digestion, microbial synthesis and nitrogen transformations in sheep. Br. J. Nutr., 39 : 105-117. 1978.

2) NRC, Nutrient requirements of sheep (6th Rev. Ed.). National Academy Press. Washington, DC. 1985.

3) Sano, H., S. Matsunobu, T. Abe and Y. Terashima, Combined effects of diet and cold exposure on insulin responsiveness to glucose and tissue responsiveness to insulin in sheep. J. Anim. Sci., 70:35143520. 1992.

4) Sano, H., S. Matsunobu, M. Nakagawa and Y. Terashima, Insulin responsiveness to glucose and tissue responsiveness to insulin over the feeding cycle in sheep. J. Anim. Sci., 68: 3736-3741. 1990.

5) SAS, SAS User's Guide: Statistics (5th ED.). SAS Inst. Inc., Cary, NC. 1985.

6) SASAKI, $\mathrm{Y}$. and $\mathrm{H}$. TAKAHASHI, Insulin secretion in sheep exposed to cold. J. Physiol. (Lond.), 306 : 323-335. 1980.

7) SASAKI, $Y$. and $H$. TAKAHASHI, Insulin response to secretogogues in sheep exposed to cold. J. Physiol. (Lond.), 334: 155-167. 1983.

8) Terashima, Y., F. Ishigaki, T. Yamaguchi, H. SANO and H. ITOH, Effects of dietary energy density and feeding level on insulin secretion and glucose uptake in sheep. Anim. Sci. Technol. (Jpn.), 62: 304-307. 1991.

9) Tsuda, T., M. Fujita and K. Ambo, Metabolism of blood glucose in cold exposed sheep. Ann. Rech. Vet, 10: 373375. 1979.

10) Webtser, A.J.F., Nutrition and the thermal environment. in Nutritional Physiology of Farm Animals. (Rоok, J.A.F. and P.C. THOMAS, eds.) 639-669. Longman. London and New York, 1983.

11) WeEkEs, T.E.C., Y. SASAKI and T. TSUDA, Enhanced responsiveness to insulin in sheep exposed to cold. Am. J. Physiol., 244 : E 335-E 345. 1983. 
Insulin Response and Action during Cold

\title{
粗飼料自由摂取めん羊におけるグルコースに対する \\ インスリン分泌能および組織に対するインスリン \\ 作用に及ぼす寒冷暴露の影響
}

佐野宏明*・大石 薫・寺島福秋

北里大学獣医畜産学部，十和田市 034

\begin{abstract}
粗飼料を自由摂取させためん羊においてグルコースに対するインスリン分泌能㧍よび組織に対するイ ンスリン作用に及ばす寒冷暴露の影響を測定するために，HGC（hyperglycemic clamp）法枋よび EGC (hyperinsulinemic euglycemic clamp) 法肪適用された。乾物搨取量は寒冷暴露によって影 響されなかった，HGC 法ではグルコース注入速度に対する血整インスリン溜度增加の割合（グルコー スに対するインスリン分必能）は寒冷暴露によって低下した $(P<0.05)$. EGC 法ではグルコース注入 速度（組織に対するインスリン作用）は常温時上りも寒冷暴露特に高功た $(P<0.01)$. 以上の結果 加ら，粗飼料を自由に撖取させても寒冷暴露によって採食量か增加しなかっため九羊では寒冷暴露時に グルコースに対するインスリン分泌能は低下し，組織に対するインスリン作用は增加することが示唆さ れた。
\end{abstract}

日畜会報, $64(10): 971-977,1993$

\footnotetext{
*見所属：岩手大学農学部，盛岡市 020
} 